\title{
The Development of CTL Based Reading Description Text Learning Material
}

\author{
Daeng Tri Fahyuan, Atmazaki, Ermanto \\ Master of Bahasa Indonesia Language and Literature Education \\ FBS Padang State University \\ daengfahyuan.df@gmail.com
}

\begin{abstract}
This research aimed to describe the validity and effectiveness of reading description text learning materials which are developed based on the principles of CTL for grade VII students. This research used the model of Plomp from prelimenary phase, development, up to asssesment phase. Validation of learning materials are described in four categories; material, presentation, language, and graphics. It uses validation sheet and test carried out in class VII SMP Negeri 12 Padang (about 31 students)by using achievement test and questionnaire. These results indicate that the learning materials developed in terms of feasibility is declared invalid content, presentation, linguistic, and graphicism have very valid and effective which is indicated by the results of student learning. Based on the results of the analysis and discussion, it can be concluded that the learning materials is worth a read text descriptions used in teaching reading skills. It is expected that this reading instructional materials can overcome the limitations of reading learning materials in junior high school.
\end{abstract}

Keywords-learning materials; reading skill; description texts; CTL

\section{INTRODUCTION}

The learning of reading skill is a priority in Indonesian language learning in junior high. In the national curriculum, among 32 basic competencies (KD) that must be studied by first grade students, there are 16 competence begins with reading, after it had studied the speaking and writing skills (Kurikulum Nasional, 2013). Reading skill is critical in studying other subjects, therefore Reading Skill is called as the window of knowledge. Bahasa Indonesia is chosen to integrate the Natural Science (IPA) and Social Science (IPS). Integrating IPA and IPS into Curriculum of Bahasa Indonesia leads it to be a key in knowledge and science discovery (Suwandi, 2013).

Recently, the recent researches on Reading skill tend to focus on its learning material. Learning material is very important thing in reading. It will be difficult to engage students to read, while learning material is not as it is shoud be. The learning materials for reading can be varied. For instance, comic (Iwahori, 2008; Roozafzai, 2012), hypermedia (Hamdan, Mohamad, and Shaharuddin, 2017), or any other materials with particular qualifications (Nordin R, 2017). Moreover, learning materials will greatly assist students' understanding of texts and materials which have not been previously known by the students.

One of the many texts that are taught in the curriculum 13 is a text description. Text Description Text or Report Text is a text that presents some information on a matter as it is. This text is a systematic description and analysis. Moreover, description text usually contains facts that can be proven scientifically. The object being observed is usually general (Wahono, et al., 2013, p. 7). Learning to read description text of the subject premises Language Curriculum 2013 for the junior class VII exposed in the core competencies (KI) 3. Core Competence (KI) 3 that understands knowledge (factual, conceptual and procedural) based on taste ingintahunya about science, technology, arts, culture and events related to the phenomenon of the visible. Meanwhile, Basic Competency (KD) for learning to read text descriptions contained in KD 3.1 of identifying information in description text of the object (schools, tourist attractions, historic sites, and performing arts or the atmosphere of the area) heard and read. In addition, there are also at KD 3.2, ie to the structure and rules of the language of description text of the object (schools, tourism objects, historic sites, and performing arts or the atmosphere of the area) heard and read. Based on what has been outlined in the curriculum, it appears that reading description text of the subject matter is one that must be learned and mastered by the students so that they are able to describe objects and events that are encountered in everyday life. tourist attractions, historic sites, and performing arts or the atmosphere of the area) heard and read. In addition, there are also at KD 3.2, ie to the structure and rules of the language of description text of the object (schools, tourist attractions, historic sites, and performing arts or the atmosphere of the area) listened and read. Based on what has been outlined in the curriculum, it appears that reading description text of the subject matter is one that must be learned and mastered by the students so that they are able to describe objects and events that are encountered in everyday life. tourist attractions, historic sites, and performing arts or the atmosphere of the area) heard and read. In addition, there are also at KD 3.2, ie to the structure and rules of the language of description text of the object (schools, tourist attractions, historic sites, and performing arts or the atmosphere of the area) heard and read. Based on what has been outlined in the curriculum, it appears that reading description text of the subject matter is one that must be learned and mastered by the students so that they are able to describe objects and events that are encountered in everyday life. and performing arts or the 
atmosphere of the area) heard and read. Based on what has been outlined in the curriculum, it appears that reading description text of the subject matter is one that must be learned and mastered by the students so that they are able to describe objects and events that are encountered in everyday life. and performing arts or the atmosphere of the area) heard and read. Based on what has been outlined in the curriculum, it appears that reading description text of the subject matter is one that must be learned and mastered by the students so that they are able to describe objects and events that are encountered in everyday life.

From the observation in the field, it is shown that the learning materials are used only as the textbook for students. In the textbook the materials provided do not suitable the needs of students in terms of the presentation of the material and the task is not attractive, so it does not provide motivation for students to read. In terms of sample text, description text used in the classroom were close to student life, so that, it makes it difficult for students to understand the text and make the students so lazy to read.

Presentation of learning materials should be easy to understand, it is also expected that the use of language could be more communicative, illustrations fuller material and color, as well as the association between the subject matter with the aim of learning and student life. Therefore, we need a valid learning materials (decent in terms of material, presentation, language, and graphics) to support student learning activities. Selection of a valid development of teaching materials to overcome the problems of students in reading skills is motivated by several factors. First, teaching materials contain descriptions of learning materials, learning orientation, and can be adapted to the development of students (Saputro, 2017, p. 192). Second, teaching materials is one of the important components that affect students' creativity in teaching reading skills (Andheska, 2016, p. 55). Third, the teaching material is flexible / easy to understand, practical, fun, comes with clear instructions, contains a complete description of the material, along with examples and exercises (Roselina, 2014, p. 44). Fourth, teaching materials should be developed based on specific learning approach that has a foundation and direction are important in learning activities in schools (Sumardi, 2000; Muslich, 2011).

In order for a valid instructional materials and can be more effective inovatid, then one approach that can be used in teaching materials reading is the approach Contextual Teaching and Learning (CTL). Contextual Teaching and Learning (CTL) is a blend of many good teaching practices, by linking the knowledge acquired and owned by the student with everyday life. Students work and experience for themselves the knowledge gained so hopefully learning becomes more meaningful (Murtiani, 2012, p. 2). Additionally, (Jonson, 2010, p. 58) also states that the Contextual Teaching and Learning (CTL) is a learning system that matches the brain that produce meaning by linking academic content to the context of students'everyday life. In this case, presentation of learning materials for reading in accordance with the structure of materials development based Contextual Teaching and Learning (CTL). The structure of teaching materials adapted to the CTL component, namely constructivism, find, asking, learning community, modeling, reflection and authentic assessment (Trianto, 2009, p. 111-119). Based on the issues raised, we need a resource that can attract students to study and help students learn. Must be a viable resource available in terms of material, presentation, language, and graphics (Lopez-Medina, 2016). Preparation of teaching materials aimed to provide a reference other than textbooks distributed by the government.

Based on the background of the problem, formulation of the problem in this research are as follows : How is the process of developing teaching materials to read text-based description of Contextual Teaching and Learning (CTL) is valid and effective? Based on the formulation of the problem, the purpose of this study was to describe the process of the development of models of teaching materials to read the description text-based Contextual Teaching and Learning (CTL) are valid (as seen from the feasibility content, language, presentation, and graphicism) and effective (as seen from the student activity, learning outcomes, and affective student).

\section{METHOD}

This resesarch uses a model of Plomp. The development process is done in three stages, namely (a) the initial stage (prelimenary research), (b) the stage of development (prototyping phase), and (c) the assessment phase (assessment phase). In this study, the product is developed in the form of teaching materials that are beneficial to the learning process in schools. The product was developed based Contextual Teaching and Learning (CTL).

The type of data in this research is qualitative and quantitative. Qualitative data obtained from classroom observations and opinions of teachers and students about the material through interviews while quantitative data obtained from filling the questionnaire validity and test students' reading ability. Subjects tested in this study were students of class VII SMPN 12 Padang totaling 31 people, one teacher, four lecturers of Padang State University who are experts in their respective fields. The data analysis technique used is descriptive data analysis techniques. Descriptive analysis performed using descriptive statistics.

\section{Stage Prelimenary Research}

\section{FINDING AND DISCUSSION}

This phase consists of four steps, ie, requirements analysis, analysis, students, curriculum analysis, and analysis of the concept. Here is further explanation of these four steps. First, the needs analysis. This phase is done by making 
observations to the school by conducting interviews with teachers. Pursuant to the results of these interviews, it can be concluded as follows (1) The ability of the students in the different reading skills. In addition to the different abilities, learned texts factor also affects the activity of learning to read. The closer the text to be examined with a student's life, the better also the students' understanding of the text. In addition, the learning materials that are difficult to make students tend not serious in learning. More than half of the students are already well in understanding the text read, although there are some students who still do not achieve the learning objectives. (2) The sources of learning used in reading decription text learning materials issued by Kemendikbud, addition to the book, the other supporting books are not available in the library, only the old books that no longer fit the curriculum of 2013. Students are also advised to read Additional resources can be found on the internet, but the internet is the source of truth is still doubtful source. In addition, students also need to be supervised when looking for a learning resource from the internet, if not monitored can make students turn to other things that are not berhubungungan to learning.

In addition to conducting interviews with teachers, interviews were conducted with two students named Ayna Nabila Rahmi and Salti Dilfani. Based on interviews with narsumber first, it is stated that the material used in the book is not too full, and not close to their environment. The students expect any other additional learning resources in learning. So that learning becomes interesting, motivating, and meyenangkan. The second speaker stated that the material contained in the textbooks in use today is still not complete, but it is less interesting to see the book, so we need another book to support pembelajaran. According to the interview, it also can be concluded that students need learning resources according to their characteristics, either in terms of material, the use of language, images,

Based on the results of the needs analysis, we concluded that students need learning resources according to their characteristics, both in terms of use of letters, pictures, color combination, to the use of communicative language. One of the learning resources that can be used is the teaching materials. The learning materials should be in accordance with the needs of students, and can raise students' motivation to learn.

Second, analysis of curriculum. Curriculum analysis performed to establish the core competencies and basic competencies that will be used to create teaching materials. The results of the analysis of curricula in this study can be seen in the following tebel.

Table 1. Analysis Curriculum

\begin{tabular}{|c|c|}
\hline Core Competence (K1) & Basic Competency (KD) \\
\hline $\begin{array}{l}\text { Understanding of knowledge (factual, } \\
\text { conceptual and procedural) based on } \\
\text { curiosity about science, technology, arts, } \\
\text { culture and events related to the visible } \\
\text { phenomena. }\end{array}$ & $\begin{array}{l}\text { Identify the information in description text of the } \\
\text { object (schools, tourist attractions, historic sites, } \\
\text { and the atmosphere of local art performances) } \\
\text { heard and read. } \\
\text { To review the structure and elements of text } \\
\text { linguistic description of the object (schools, } \\
\text { tourist attractions, historic sites, and the } \\
\text { atmosphere of local art performances) heard and } \\
\text { read. }\end{array}$ \\
\hline
\end{tabular}

Third, Analysis of the students. This analysis was conducted to examine the character of the students that will be used as consideration in designing instructional materials will be developed. in this case is a gradeVII students of SMP 12 Padang. Based on the research results obtained the following data.

Table 2. Characteristics of the Students

\begin{tabular}{llccc}
\hline No. & \multicolumn{1}{c}{ Rated aspect } & Score & $\begin{array}{c}\text { Value } \\
(\%)\end{array}$ & Category \\
\hline 1. & $\begin{array}{l}\text { Identifying traits, abilities, and experiences of } \\
\text { students both as individuals and as a group. }\end{array}$ & 518 & 80.94 & High \\
\hline 2. & Seeing the students' reading habits & 383 & 59.81 & Moderate \\
\hline 3. & Seeing the students' interest & 306 & 59.77 & Moderate \\
\hline 4. & Identifying students' reading skills. & 558 & 72.66 & High \\
\hline & Amount & 1.765 & 68.29 & Moderate \\
\hline
\end{tabular}

Fourth, Analysts concept. Analysis of the concept aims to define the content of the material in the resource description read text-based description of Contextual Teaching and Learning (CTL). For more details, concepts read the description text can be seen in Table berikuit. 
Table 3. Analysis of the Concepts

\begin{tabular}{l}
\hline \multicolumn{1}{c}{ Description Description Text Reading Concepts } \\
\hline a. Definition of description text \\
b. The characteristics of description text \\
c. Pattern description text presentation \\
1. Text description of the stand-alone \\
2. Description texts that are part of another text \\
d. Structure description text \\
1. Identification \\
2. Description of parts \\
3. Cover \\
e. Feature linguistic description text
\end{tabular}

Prototyping Research (development stage)

First, Self evaluation. This stage is carried out by the researchers themselves by filling out a questionnaire. It aims to check the teaching materials developed before being validated by experts. If there are errors then teaching materials that have been made revised first. The results of the validation can be seen in the following table.

Table 4. Self Evaluation Instructional Materials

\begin{tabular}{llccc}
\hline No. & \multicolumn{1}{c}{ Rated aspect } & Score & Validity (\%) & Category \\
\hline 1. & Feasibility contents of teaching materials & 72 & 100 & very valid \\
\hline 2. & Language teaching materials & 24 & 100 & very valid \\
\hline Results of Self-Evaluation Validation Entire & & 100 & very valid \\
\hline
\end{tabular}

Second, Test the validity of teaching materials by experts. It aims to obtain high quality materials and fit for use in learning. Validation is important to obtain teaching materials have been developed. Validated teaching materials must meet the criteria of validity in terms of content, language, presentation, and the graphic. At this stage involves four experts who are experts in their respective fields. The validation results are described as follows.

Table 5. Results of Validation of Teaching Material by Expert

\begin{tabular}{|c|c|c|c|c|}
\hline No. & Rated aspect & Score & Validity (\%) & Category \\
\hline 1. & $\begin{array}{l}\text { Feasibility contents of teaching } \\
\text { materials }\end{array}$ & 70 & 97.22 & very valid \\
\hline 2. & Language teaching materials & 24 & 100 & very valid \\
\hline 3. & Presentation materials & 78 & 97,50 & very valid \\
\hline 4. & Kegrafikaan teaching materials & 36 & 100 & very valid \\
\hline \multicolumn{3}{|c|}{ Validation of the overall teaching materials } & 98.68 & very valid \\
\hline
\end{tabular}

Third, teachers' responses toward the learning materials. The teacher's response is part of the validity of the test conducted by the teacher. This is done to determine the validity of teaching materials developed before tested in schools. The validity of the value obtained by using a questionnaire filled out by three teachers at the school study. The results of the teacher's response can be seen in the following table.

Table 6. Results of Response Teachers

\begin{tabular}{llccc}
\hline No. & \multicolumn{1}{c}{ Rated aspect } & Score & Validity (\%) & Category \\
\hline 1. & $\begin{array}{l}\text { Feasibility contents of teaching } \\
\text { materials }\end{array}$ & 3 & 100 & very valid \\
\hline 2. & Language teaching materials & 3 & 100 & very valid \\
\hline 3. & Presentation materials & 4 & 100 & very valid \\
\hline $4 . \quad$ Kegrafikaan teaching materials & 4 & 100 & very valid \\
\hline Validation of the overall teaching materials & & 100 & very valid \\
\hline
\end{tabular}

\section{Assessment Phase (assessment phase)}

The effectiveness of teaching materials obtained from three sources, namely the student activity and cognitive test results read text descriptions. Both figures are described as follows.

First, Student learning activities. Student activity obtained through observation sheet student learning activities. The student activity data collected by the teacher as the first observer, and investigators as a second observer. The first 
observer observing the activity of 16 students and a second observer observe 15 students. The division's observation activities adapted based on the order the students' attendance list. The observations were made at each meeting. This observation aims to look at the suitability of the activities expected to appear in description text of students studying with teaching materials. For more details about this stage can be seen in the following table.

Table 7. Analysis of Student Learning Activities

\begin{tabular}{llccc}
\multicolumn{5}{c}{ Table 7. Analysis of Student Learning Activities } \\
\hline No. & \multicolumn{1}{c}{ Statement } & $\begin{array}{c}\text { frequency } \\
\text { of activity }\end{array}$ & $\begin{array}{c}\text { percentage } \\
\text { of activity }\end{array}$ & Category \\
\hline 1. & $\begin{array}{l}\text { Studying the teaching materials in accordance } \\
\text { with the instructions provided }\end{array}$ & 57 & 91.93 & Very active \\
\hline 2. & $\begin{array}{l}\text { Digging for information or comprehension } \\
\text { based learning topics }\end{array}$ & 53 & 85.48 & Active \\
\hline $3 . \quad \begin{array}{l}\text { Find out for yourself by reading the concept of } \\
\text { learning topics }\end{array}$ & 55 & 88.70 & Very active \\
\hline $\begin{array}{l}\text { Obtaining information through activity based } \\
\text { learning topics asked. }\end{array}$ & 58 & 93.54 & Very active \\
\hline $\begin{array}{l}\text { Cooperate and a variety of learning } \\
\text { experiences with group }\end{array}$ & 59 & 95.16 & Very active \\
\hline $\begin{array}{l}\text { Carried out an inquiry to identify the examples } \\
\text { provided. }\end{array}$ & 58 & 93.54 & Very active \\
\hline Presenting instructional feedback. & 55 & 88.70 & Active \\
\hline Working on performance tests appropriate \\
given problem
\end{tabular}

Second, the results of cognitive tests on reading description text. The results obtained through a test of knowledge (cognitive). The results of cognitive tests on students reading test is a reference to determine the effectiveness of the CTL based reading description text learning materials for grade VII . This data is collected at the last meeting of the testing phase of the product. For more details about this stage can be seen in the following table.

Table 8. Analisis Student Results

\begin{tabular}{lcccc}
\hline No. & Subject (31 0rang) & Total score & Value & Changed Value \\
\hline AMOUNT & 1335 & 2670 & \\
\hline AVERAGE & 43.06 & 86.12 & \\
\hline PREDICATE & & & $\mathrm{A}$ \\
\hline
\end{tabular}

So,based on the description above, it can be concluded that the CTL based reading description text learning materials for grade VII are valid and practical. From the analysis of the validity of the materials obtained from percentage of the overall average score of $98.68 \%$ with a very valid category. Very valid assessment of the teaching materials developed indicates that learning material can be used as a guideline in the implementation of the learning process.It is suitable with the ideas of Plomp (2013, p. 29) states that the characteristics of the product are considered valid if the product components are based on the principle of knowledge. It is called the content validity. Furthermore, these components must also be associated consistently with one another or also called as the construct validity. In this validation study further divided into product validation performed on the material (content), language, presentation and kegrafikaan. Above all, for effectiveness, learning materials can be considered effective if the learning process by these materials student scores are above the KKM. According Trianto (2010, p. 235) KKM is determined by educational units (each school). Based on the analysis of the results of students in aspects of knowledge, learning to use the materials read text-based description of contextual teaching and learning can help students understand the material in order to obtain a good result.

\section{CONCLUSION}

According to the results of the development that has been done, it can be concluded that the teaching materials that have been made are validated to see its validity,so that it can be used to stage effectiveness. The CTL based reading description text learning materials for grade VII can be categorized very valid. It can be seen from the overall validity of the teaching materials with the acquisition of the validity of the value of 98.68 with very valid category. As for the effectiveness of the values obtained an average of $86.12 \%$ which is above the KKM. So, the materials can be categorized as effective materials. 
Based on the results, it is expected that teachers are able to develop their own teaching materials to be used as learning materials accompanying the main teaching materials which should be suitable with students' needs and can be linked to real-life contexts of students mainly for reading ability.

\section{References}

H. Andheska, "Developing creativity of students in learning to write by utilizing innovative instructional media, Bahastra, Vol. XXXVI, No. 1, Pg. 55-67, 2016.

Hamdan, NA, Mohamad, M., \& Shaharuddin, S. (2017). Hypermedia Reading materials: undergraduate perceptions and features affecting Reviews their reading comprehension, 15 (2), 116-125.

Iwahori, Y. (2008). Developing Reading Fluency: A Study of Extensive Reading in EFL. Reading in a Foreign Language, 20 (1), 70-91.

Johnson, EB. (2010). Contextual teaching and learning: to make teaching and learning exciting and meaningful. Translation Ibnu Setiawan. Bandung: MLC.

López-Medina, B. (2016). Developing a CLIL textbook evaluation checklist. LACLIL, 9 (1), 159-173. doi: 10.5294 / laclil.2016.9.1.7

Murtiani. (2012). Implementation approach Contextual Teaching and Learning (CTL) based lesson study to improve the quality of teaching of physics in the country smp desert city. Physics Education Research Journal. Volume 1, Number 12, Pg. 2.

Muslich, M. (2011). Text book writing, the basics of comprehension, writing, and the use of textbooks. Yogyakarta: ArRuzz Media.

N. Saputro, "Development of textbook writing short stories-oriented character of love of the homeland," Journal Indonesian Language and Literature Education, Vol. 2, No. 2, Pg. 192-202, 2017.

Nordin, R. (2017). Text-Selection for Tertiary Teaching Reading to ESL Students: A Study on Genre and Content Preferences, 10 (1), 71-84.

Plomp, Tj. (2013). Educational design: intoduction from tjerd plomp (eds). Educational \& training system design: introduction. Design of education and training (in dutch). Utrecht (The Neterlands): Lemma Netherlands. Faculty of Educational Science and technology, University of twente.

Roselina, "Development of learning modules write poetry based on stylistic approach for high school students," Lingua, Journal of Language and Literature, Vol. 15, No. 1, pp. 44-53, 2014.

Roozafzai, ZS (2012). The role of comic reading material in enhenceing the ability to read in EFL. I-Manager's Journal o English Language Teaching, 2 (3), 7-15.

Sumardi. (2000). Indonesian elementary school textbooks as a means of personal development, reasoning, creativity, and communication skills of children. Jakarta: Grasindo.

Suwandi, S. (2013). "Learning Indonesian sanitifik text-based approach." Paper presented at the national seminar Indonesian learning and curriculum 2013 Veteran Bangun Nusantara University Sukoharjo, 2013.

Trianto. (2009). Designing innovative learning model-progressive. Jakarta: Kencana.

Trianto. (2010). Pengantar penelitian pendidikan. Jakarta: Kencana.

Wahono. (2013). Proficient in Indonesia for smp / mts class vii. Jakarta: Erland.

Revelation, A. (2012). Effect of chemical learning approach CTL (contextual teaching and learning) through experimental methods and projects on learning achievement in terms of students' interest in entrepreneurship in the material class x smk domestic distilled 2 Sukoharjo academic year 2011/2012. Journal of Chemical Education. Volume 1, Number 1. Pg 81. 